\title{
PRAWO DO WŁASNOŚCI I SPOSÓB JEJ UŻYTKOWANIA W ŚWIETLE ,DE NABUTHAE HISTORIA” ŚW. AMBROŻEGO Z MEDIOLANU
}

W diatrybie De Nabuthae historia św. Ambrożego czytamy między innymi:

„Bogacze, jak daleko będą sięgać wasze szalone pragnienia? Czy sami będziecie zamieszkiwać ziemię? Dlaczego wykluczacie z dziedzictwa tego, kto posiada tę samą ludzką naturę i sobie jedynie uzurpujecie posiadanie przyrody. Ziemia została stworzona na wspólny użytek wszystkich ludzi, bogatych i ubogich. Dlaczego więc, wy bogacze, przywłaszczacie jedynie sobie wyłączne prawo do niej?"1.

W innym natomiast miejscu tego samego dzieła Biskup Mediolanu stwierdza:

\begin{abstract}
„Nie obdarowujesz przecież biedaka ze swego, lecz zwracasz mu to, co jest jego własnością. Sam bowiem przywłaszczasz jedynie sobie to, co należy do wszystkich i zostało dane na wspólny użytek. Ziemia należy do wszystkich, nie tylko do bogaczy. Mniej jest jednak tych, którzy nie korzystają ze swojej własności niż tych, którzy używają jej. Nie robisz więc łaski dając, lecz zwracasz tylko to, co się innym słusznie należy"2.
\end{abstract}

Te dwie wypowiedzi mogłyby wskazywać, że św. Ambroży z Mediolanu wypowiada się w wyraźny sposób za społeczną własnością. Ziemia i jej dobra należą do wszystkich ze względu na naturalną równość wszystkich ludzi. Czy Ambroży rzeczywiście odrzuca indywidualną prywatną własność, a w jego wypowiedziach można zauważyć zwiastuna nauki komunistycznej?

Okazją do szerszej wypowiedzi dla Ambrożego jest we wskazanym dziele historia biblijnego Nabota, opisana w 1 Krl 21, 1-29. Król Achab przy pomocy sądowego zabójstwa zagarnął dla siebie winnicę, która należała do Nabota, dokonał więc agresji na jego prywatną własność. Ambroży wyraźnie piętnuje tę postawę królewską. Za naganne uznaje po pierwsze u króla Achaba pożądanie cudzej własności:

${ }^{1}$ De Nabuthae historia 2, CSEL 32/2, 469-470, thum., wstęp i oprac. M. Kozera: Historia Nabota, Sandomierz 1985, 28.

${ }^{2}$ Tamże 53, CSEL 32/2, 498, Kozera s. 58. 
„Wyznaje, że ona nie jest jego i domaga się jej, pomimo że mu się nie należy. «A ja dam ci za nią inną winnicę» (1 Krl 21, 2), mówi. Bogacz gardzi tym, co jest jego, nisko to sobie ceni, pożąda natomiast cudzej własności jako czegoś bardzo cennego"3.

Na tle postawy króla, bogacza czyhającego na cudzą własność, Biskup Mediolanu ukazuje Nabota, biedaka, który słusznie broni dziedzictwa swoich przodków:

„Wysłuchaliśmy głosu bogacza czyhającego na cudzą własność. Posłuchajmy teraz biedaka, który broni swego. Mówi on: «Niech mnie Bóg broni przed tym, abym miał ci oddać dziedzictwo mych przodków». Pieniądze bogacza są dla niego jak jakaś zaraza. Zda się mówić: «Niech pieniądze twoje przepadną, razem z tobą» (Dz $8,20)$. Ja nie mogę sprzedać mojej ojcowizny. I ty, bogaczu, jeśli jesteś rozumny, masz zasady, którymi się kierujesz. Nie oddałbyś swego pola w zamian za noc $\mathrm{z}$ nierządnicą. Twego prawa własności nie roztrwoniłbyś na marnotrawnych hulankach, ani w kosztownych zabawach. Nie uczyniłbyś swego domu stawką przy grze w kości. Nie straciłbyś też prawa do spadku po rodzicach" ${ }^{4}$.

Jako wielce słuszna jawi się Ambrożemu postawa Nabota, który broni swojej ojcowizny, jako w pewnym sensie rzeczy świętej, nie chce oddać nawet w zamian za inną posiadłość czy też za pieniądze. Takiej postawy zresztą trudno byłoby oczekiwać od króla Achaba. Nikt nie musi za jakąkolwiek cenę pozbywać się prawa do własności. W traktacie Obowiązki duchownych św. Ambroży, gdy czyni wykład na temat wartości cnót kardynalnych, podkreśla, że sprawiedliwość jest cnotą, która stoi na straży cudzych praw, broni własności i czuwa nad tym, by oddać każdemu, co mu się należy ${ }^{5}$.

Święty Ambroży, gdy w 374 r. został w niespodziewany dla siebie sposób biskupem Mediolanu, oprócz intensywnej działalności duszpasterskiej, angażuje się w bardzo widoczny sposób w ówczesne sprawy natury politycznej i społecznej. Uważa się go za wyjątkowego apostoła społecznego ${ }^{6}$. Sam rozdaje swój znaczny majątek ubogim. $Z$ wielką energią piętnuje w swoich kazaniach, listach czy innych dziełach ówczesne nadużycia o charakterze ekonomicznym, szczególnie nadużycia w zakresie własności. A ówczesne życie gospodarcze i społeczne Cesarstwa Rzymskiego charakteryzowało się wielkimi dysproporcjami. Zniknęła wówczas w praktyce klasa średnia wchłonięta przez wielką własność ziemską, a wolni rolnicy zostali praktycznie zrównani z kolonami. Na skutek wielkiej eksploatacji doprowadzano ich do nędzy, a w związku z tym często do zbrojnych buntów. Nie lepsza sytuacja panowała także

3 Tamże 9, CSEL 32/2, 473, Kozera s. 32.

${ }^{4}$ Tamże 13, CSEL 32/2, 475, Kozera s. 33-34.

5 Por. De officiis ministrorum II 9, 49, PL 16, 123C, thum. K. Abgarowicz (Sw. Ambroży z Mediolanu, Obowiazki duchownych, Warszawa 1967), 129.

${ }^{6}$ Por. A. Hamman, Portrety Ojców Kościoła. Praktyczny przewodnik po patrologii, tłum. zbiorowe, Warszawa 1978, 178. 
w miastach. Ucisk fiskalny dosięgał różne grupy mieszkańców miast. Mieszkańcy coraz bardziej ubożeli, wzrastała ilość żebraków. Wraz z tym pogłębianiem się nędzy wielkiej liczby mieszkańców cesarstwa, gwałtownie wzrastała wówczas zamożność bardzo wąskiej elity, która zagarniała majątki biedaków i warstwy średniej. W rękach samego dworu cesarskiego, wyższych wojskowych i wyższych urzędników cywilnych znalazła się olbrzymia większość ziemi ${ }^{7}$.

Zaangażowany w sprawy społeczne biskup Ambroży, w dziele poświęconym historii biblijnego Nabota, nie ogranicza się więc tylko do egzegezy tej biblijnej perykopy. Stanowi ona, jak i drugi tekst biblijny, mianowicie przypowieść o bogaczu, któremu dobrze obrodziło pole ( $\mathrm{kk} 12,16-21)$, okazję, by przez egzegezę tekstów biblijnych zabrać głos jako nauczyciel moralności chrześcijańskiej w aktualnych sprawach życia społecznego. Już pierwsze zdania dzieła o Nabocie wskazują, że Ambroży chce zabrać przede wszystkim głos w sprawach aktualnych w jego czasach, sprawach, które działy się także na jego oczach w jego diecezji. Biskup Mediolanu wskazuje na aktualność problemów, jakie niesie ze sobą historia Nabota:

„Historia Nabota, choć wydarzyła się dawno, powtarza się każdego dnia. Czy jest bowiem jakiś bogacz, który nie patrzy łapczywie każdego dnia na cudzą własność? Czy jest możnowładca, który nie usiłuje wypędzić biedaka z jego skrawka ziemi, a ubogiego wyrzucić z ojcowskiego zagonu? Czy ktoś z nich zadawala się tym, co posiada? Czy bogacza nie nęci zawsze posiadłość leżąca w pobliżu? A więc nie ten jeden tylko Achab urodzil się, lecz co gorsza, codziennie rodzi się taki Achab, a nigdy nie schodzi z tego świata. Jeśli umrze jeden, rodzą się inni, jeszcze liczniejsi. Więcej jest tych, którzy gotowi są zabierać, niż tych, którzy mogliby utracić. Nie tylko jeden biedak - Nabot - został zabity. Codziennie taki Nabot ponosi śmierć, codziennie ginie biedak. Nękani tego rodzaju groźbą ludzie ustępują w końcu ze swej ziemi. Wędruje więc biedak z maleńkimi dziećmi, najbliżsi są mu ciężarem. Zapłakana żona idzie za nim, jak gdyby odprowadzała męża do grobu"s.

Powyższe słowa Ambrożego z całą pewnością trafnie wyrażają cały dramatyzm, jaki niosła za sobą ukazana powyżej sytuacja gospodarczo-społeczna Cesarstwa Rzymskiego w jego czasach.

Pilnie śledząc ówczesne stosunki gospodarczo-społeczne, Ambroży nie piętnuje ludzi bogatych za to, że posiadają określone dobra. Podstawowy zarzut, jaki stawia wobec tych ludzi, oceniając ich postawę w kategoriach moralnych, to chciwość. Ludzie bogaci ogarnięci tą wadą ponad miarę gromadzą dla siebie dobra materialne, kumulując w swoich rękach wielkie majątki przez zagarnianie dóbr ludzi uboższych i doprowadzanie tych ostatnich do ruiny

${ }^{7}$ Por. M. Kozera, Wprowadzenie, w: Swięty Ambroży, Historia Nabota, Sandomierz 1985, $13-14$

${ }^{8}$ De Nabuthae 1, CSEL 32/2, 469, Kozera s. 27. 
majątkowej. Chciwość ta powoduje, że w ciągu życia targa nimi nieustanny niepokój, jaki spowodowany jest coraz to większym gromadzeniem dóbr wyłącznie we własnych rękach. Ich postawa jest bliska tej, jaką przedstawił Jezus w przypowieści o bogaczu, który jednego roku zebrał szczególnie obfite plony:

„Chciwość zrywa go ze snu. Dręczy go ustawicznie pragnienie, by zagarnąć cudzą własność, skręca go zazdrość, niepokoi go zwłoka, przerażają go niskie dochody i nieurodzaj, nie dają spokoju obfite plony [...]. Nie tylko Bóg nie pozwala mu spać spokojnie, nasuwając mu myśli, gdy się zastanawia, budząc w czasie snu. Lecz on sam także nie czuje się spokojnym, niepokojąc się z powodu wielkiego urodzaju. Mając obfite plony mówi jak ten, który cierpi niedostatek: Co tu począć? [...]. Rozwiała się nadzieja chciwca. $\mathrm{Z}$ powodu nowych zbiorów rozpadają się stare spichlerze" ".

Niespodziewanie wysokie plony powodują zmartwienie i rodzą niepokój:

„Bogaczu, nie wiesz, jak bardzo jesteś biedny, za jakiego nędzarza powinieneś sam siebie uważać, ty właśnie, który twierdzisz, że jesteś bogaty. Im więcej byś posiadał, tym większe odczuwasz braki. Im więcej byś zyskał, tym więcej będziesz jednak odczuwał potrzeb. Bogactwo bowiem nie zaspokaja chciwości, lecz jeszcze ją podsyca. Zachłanność posiada jak gdyby pewne stopnie. Im wyżej ktoś wejdzie, tym szybciej pnie się wzwyż, a stamtąd, w razie potknięcia, upadek może być wielki" ${ }^{10}$.

Chciwość nie pozwoliła bogaczowi zrozumieć, że mógłby uniknąć takiego niepokoju, gdyby zechciał podzielić się bogactwem swoich dóbr z ubogimi. Ambroży w następujących słowach wskazuje, jak chciwość nie pozwala ludziom bogatym w momencie urodzaju znaleźć lepszego rozwiązania niż stawianie nowych, większych magazynów dla gromadzenia wzrastających dóbr:

„Zobacz jak boi się, by nie wezbrała obfita fala żywności, by nie przelała się ze spichlerzy, by nie dopłynęła do biedaków, by nie stała się środkiem wspomożenia dla potrzebujących. Rości sobie wyłączne prawo do płodów ziemi, nie po to, by chciał z nich sam korzystać, lecz by inni nie mieli tego prawa"11.

Wielu bardzo bogatych ludzi po prostu źle korzysta ze swojej własności. Roszcząc sobie prawo wyłączności do korzystania z dóbr, jakie rodzi ziemia, nie tylko, że nie dzielą się tymi dobrami poprzez działalność dobroczynną, ale starają się pozbawiać ludzi ubogich wszelkich praw do jakichkolwiek dóbr.

Chciwość łączy się ponadto w postawie wielu ludzi bogatych z inną wadą, jaką stanowi pycha. Ludziom, którzy wówczas w sposób nadmierny wzbogacili się, Biskup Mediolanu stawia choćby następujące pytania:

\footnotetext{
9 Tamże 29-30 i 32, CSEL 32/2, 484-485, Kozera s. 42-44.

${ }^{10}$ Tamże 4, CSEL 32/2, 471, Kozera s. 29-30.

11 Tamże 35, CSEL 32/2 487, Kozera s. 45-46.
} 
Dlaczego się pysznisz bogaczu? Dlaczego mówisz do biedaka: nie dotykaj się mnie? Czy nie w ten sam sposób jak biedak począłeś się w łonie matki i stamtąd na świat przyszedłeś? Czemu chełpisz się arystokratycznym rodem ${ }^{12}$.

Wszyscy ludzie z natury swej są sobie równi. Natura nie potrafi rozróżniać ludzi na bogatych i biednych, a na naturalną równość ludzi wskazuje fakt ich narodzin i śmierci. Ambroży obrazuje to następująco:

\begin{abstract}
„Natura, która wszystkich rodzi jako biedaków, nie wie co to bogacz. Nie rodzimy się bowiem w odzieniu, ani nie przychodzimy na świat ze złotem czy srebrem. Nagich nas wydała matka ziemia na świat, nie mających pożywienia, napoju ani odzienia i nagich nas też przygarnia. Nie umie ona bowiem zamknąć w grobie całej posiadłości. Wąski grób wystarcza przecież zarówno bogatemu, jak i ubogiemu, a ziemia, która nie mogła nasycić chciwości żyjącego bogacza, teraz już ogarnia go całkowicie. Nie uznaje natura różnicy między nami, kiedy się rodzimy, nie zna też jej, gdy umieramy. Wszystkich w ten sam sposób powołuje do życia i wszystkich jednakowo zamyka we wnętrzu grobu. Któż wykryje różnicę pomiędzy umarłymi? Rozkop na nowo ziemię, i jeśli potrafisz, rozpoznaj bogatego. Usuń po niedługim czasie piasek $z$ mogiły i jeśli nawet poznasz, że jest to biedak, udowodnij to w inny sposób niż w ten, że wraz z bogaczem gnije bardzo wiele rzeczy" ${ }^{\prime 13}$.
\end{abstract}

Chciwość, która wyraża się w pożądaniu cudzej własności i to ludzi wiele uboższych, a także w braku woli dzielenia się swoimi dobrami z ludźmi biednymi stanowi o tym, że wielu bogatych ludzi niewłaściwie korzystało z posiadanych na własność nieraz bardzo wielkiej ilości dóbr. Ambroży wskazuje także na jeszcze jeden powód tego niewłaściwego użytkowania nagromadzonych wartości materialnych, a jest nim zniewolenie ich właścicieli. Czyni to Biskup Mediolanu w sposób następujący:

„Wyraźnie wskazał psalmista o kogo to może chodzić mówiąc: «Wszyscy ludzie bogactw» (Ps 75, 6). Powiedział: «wszyscy», a więc nie zrobil żadnego wyjątku. Słusznie powiedział o nich: «ludzie bogactw». Nie użył określenia «bogactwa ludzi», chcąc ukazać w ten sposób, że nie oni są właścicielami bogactw, lecz że bogactwa władają nimi. A przecież posiadłość powinna należeć do posiadacza, a nie posiadacz do posiadłości. Każdy więc, kto nie używa swego majątku jako czegoś, czym ma prawo dysponować, kto nie wie, co to być hojnym i obdarowywać biedaka, ten jest niewolnikiem swych dóbr, a nie ich właścicielem. Nadzoruje jedynie to, co nie jest jego własnością. Jest niczym niewolnik i nie używa tego jako właściciel, korzystający ze swojej własności. O tego rodzaju usposobieniu mówimy, że człowiek jest własnością bogactwa, a nie bogactwo własnością człowieka"14.

W innym miejscu czytamy podobne w swej wymowie słowa:

12 Tamże 54, CSEL 32/2, 499, Kozera s. 59.

13 Tamże 2, CSEL 32/2, 470, Kozera s. 28-29.

${ }^{14}$ Tamze 63, CSEL 32/2, 506-507, Kozera s. 66-67. 
„Jesteście niewolnikami bogacze i to w jakże żałosnej niewoli. Wy, którzy służycie błędowi, ulegacie żądzy. Jesteście w niewoli chciwości, której nie można nasycić. Jest bowiem, niczym jakaś otchłań nienasycona, która staje się bardziej chłonną, kiedy wchłania to, co wrzucono"15.

Człowiek, który jest właścicielem określonych ilości dóbr powinien nimi władać, a nie odwrotnie. Wlaściciel ma określone prawa, aby dysponować swoim majątkiem. Jeżeli jednak owładnie nim wada chciwości, staje się niewolnikiem własności i to ona wówczas włada właścicielem. Chciwość może sprawić ubezwłasnowolnienie właściciela, co do właściwego dysponowania majątkiem, do którego ma prawo.

Na czym zasadza się według świętego Ambrożego to właściwe dysponowanie swoim majątkiem? W analizowanym przez nas dziele Biskup Mediolanu przyrównuje własność, która stanowi o bogactwie, do cysterny:

„Cysterna bowiem, jeśli się nie odprowadza z niej wody, latwo niszczeje, dlatego, że nie jest w użyciu i jest w nienaturalnym stanie. Jeśli natomiast używa się jej, ładnie wygląda, a woda staje się smaczniejsza do picia. Podobnie i wielkie bogactwo, jeżeli zgromadzi się je, jest jak piasek, jeżeli używa się go, nabiera blasku, lecz gdy leży spokojnie staje się bezużyteczne" ${ }^{16}$.

Stąd Ambroży przypomina bogatym właścicielom ziemskim o ich podstawowym obowiązku:

„Niech twój majątek nie czeka bezużytecznie, niech nie czeka na ciebie ogień "wieczny. Oczekiwał cię będzie, jeśli nie usuniesz go czynami twego miłosierdzia"17.

Dla Ambrożego bowiem dobra same w sobie są czymś dobrym. Ocena moralna zależy od tego, w jaki sposób potrafi się nimi posługiwać człowiek, czy zdoła wykorzystywać je w ten sposób, aby także świadczyć dzieła miłosierdzia. Prawdę tę wyraża Biskup Mediolanu następująco:

Dobra są zatem czymś dobrym, dla tego, kto umie je właściwie spożytkować. Dla tego jednak, kto nie potrafi, z pewnością są czymś złym. «Rozdaje, obdarza ubogich, sprawiedliwość jego będzie trwała zawsze». Czy jest coś lepszego niż to właśnie? Dobra są czymś dobrym, jeśli hojnie obdarowujesz nimi biedaka, czyniąc się tym samym jakby wierzycielem samego Boga, który miłosierdzie zwraca z procentem. Bogactwa stają się dobrami, jeżeli otwierasz spichlerze twej prawości, byś był chlebem dla biednych, życiem dla nędzarzy, okiem dla niewidomych, ojcem dla osieroconych maleństw"18.

\footnotetext{
15 Tamże 52, CSEL 32/2, 497, Kozera s. 57.

16 Tamże, Kozera s. 57-58.

17 Tamże, CSEL 32/2, 498, Kozera s. 58.

18 Tamże 36, CSEL 32/2, 487, Kozera s. 46.
} 
Stąd mając na uwadze bogacza z ewangelicznej przypowieści, Ambroży zwraca się do sobie współczesnych, dysponujących wielkim majątkiem z następującym imperatywem:

„Masz środki, by to zrobić. Czego się więc obawiasz? Przypomnę ci twe własne słowa: «Masz wielkie zapasy dóbr na długie lata złożone» (Łk 12, 19). Możesz nie skąpić ich dla siebie, ani dla innych. Masz obfitość, która stanowi wspólną własność. Dlaczego zatem burzysz spichlerze? Wskazuję ci, gdzie lepiej możesz zabezpieczyć twe zboże, gdzie dobrze je będziesz strzegł, by złodzieje nie mogli go ukraść. Przechowuj je w sercu biedaków, gdzie nie zje go żaden wołek zbożowy, ani nie zepsuje się ze starości. Jako miejsce przechowania masz zanadrza biedaków, masz domy wdów, masz usta dzieci, by można było powiedzieć o tobie: "Sprawiłeś, że usta dzieci i niemowląt oddają ci chwałę" (Ps 8, 3). Są to składy, które mogą przetrwać na wieki, są to spichlerze, których nie będzie w stanie nigdy rozsadzić przyszły urodzaj"19.

W tych słowach Biskupa Mediolanu padają bardzo ważkie sformułowania, które pozwalają zrozumieć, jaki jest stosunek św. Ambrożego do prawa własności i sposobu jej użytkowania. Słowa z przypowieści ewangelicznej: „Masz wielkie zapasy dóbr na długie lata złożone", stanowią o własności jakiegoś człowieka i biskup Ambroży nie neguje, że człowiek ten ma do tej własności prawo. Za tymi słowami następują jednak kolejne: „Możesz nie skąpić ich dla siebie, ani dla innych. Masz obfitość, która stanowi wspólną własność". Słowa te wyrażają istotną myśl Ambrożego co do użytkowania dóbr, jakie pochodzą z prywatnej własności. Prawo do korzystania z owoców własności ma właściciel, ale także i inni, do których należą ci, którzy cierpią biedę materialną. Te słowa pozwalają nam także lepiej zrozumieć sens sformułowań Ambrożego na temat własności cytowanych na początku. Biskup Mediolanu akceptuje własność prywatną, lecz, możemy tak powiedzieć, nakłada na nią pewne ograniczenia, które tkwią w prawie naturalnym, jakie jest dziełem Stwórcy. On stworzył ziemię dla wszystkich ludzi, bogatych i biednych, którzy co do natury są sobie równi. Żaden właściciel nie może sobie uzurpować wyłącznego prawa do korzystania z dóbr, jakie rodzi ziemia, jeśli nawet jest ona jego własnością. Obfitość owoców, jakie ziemia wydaje, stanowi własność wspólną. Wykorzystywanie dóbr pochodzących z własności prywatnej powinno mieć więc charakter publiczny i społeczny, a dokonuje się ono przede wszystkim na skutek charytatywnej i dobroczynnej działalności właścicieli ziemskich.

Obowiązek dobroczynności, jak wskazują na to przedstawione teksty z analizowanego dzieła, wynika według Ambrożego z woli Bożej, z prawa naturalnego i z przeznaczenia dóbr, jakie są owocem ziemi. Według zasady, jaką proponuje Ambroży w dziele dotyczącym sprawy Nabota, działalnością

19 Tamże 37, CSEL 32/2, 487-488, Kozera s. 46-47. 
dobroczynną powinni być objęci wszyscy. Biskup Mediolanu nie czyni tutaj w tym względzie żadnych zastrzeżeń:

„Nie powinieneś też pytać, czy ktoś zasługuje na pomoc. Miłosierdzie przecież nie zwykło zważać na zasługi, lecz przychodzi z pomocą tym, którzy potrzebują. Nie patrzy na zasady sprawiedliwości, lecz wspiera biedaków"20.

Jakkolwiek należy zaznaczyć, że w dziele Obowiązki duchownych, Ambroży poświęcając cały rozdział kwestii, kogo należy obejmować działalnością charytatywną, czyni pewne zastrzeżenia. Po pierwsze, w zmodyfikowany nieco sposób podaje tutaj zasadę ogólną:

„Oczywiście, Bóg nie ma względu na osobę ludzką, ponieważ jest wszechwiedzący. My zaś winniśmy wprawdzie wszystkim okazywać miłosierdzie, lecz ponieważ wielu podstępnie upomina się o nie i udaje strapionych, przeto tam, gdzie sprawa jest jasna, osoba znana i czas nagli, miłosierdzie powinno hojniej udzielać swych darów"21.

$\mathrm{Z}$ zasady więc miłosierdzie według Biskupa Mediolanu powinno obejmować wszystkich potrzebujących, jednak w praktyce życia zawsze będą ludzie, którzy bardziej lub mniej zasługują na szczodrobliwość wynikającą ze świadczenia dzieł miłosierdzia. Przykładowo niestosowną rzeczą byłoby wspomaganie tych, którzy pozyskane tą drogą dobra materialne przeznaczaliby na życie w grzechu, działalność przeciw ojczyźnie bądź Kościołowi ${ }^{22}$. W szafowaniu dobroczynnością należy, zdaniem Ambrożego, zwracać także uwagę na wiarę, słuszną przyczynę, miejsce i czas. Na tej podstawie na przykład pierwszeństwo do pomocy mają ci, którzy są jednej wiary ze świadczącymi dzieła miłosierdzia ${ }^{23}$.

Człowiek bardzo bogaty, który dysponuje nawet wielką własnością ziemską, jeśli we właściwy sposób wykorzystuje swoje dobra zarówno dla siebie, jak i umie dzielić się nimi z ludźmi potrzebującymi, może w ten sposób zapewnić sobie zbawienie. Ambroży przytacza słowa Jezusa: „Zaprawdę, powiadam wam: Bogaty z trudnością wejdzie do królestwa niebieskiego" (Mk 10, 23), które On wypowiedział, gdy pewien bogaty młody człowiek nie przyjął oferty naśladowania Go, wyrażającej się w słowach: „Jeśli chcesz być doskonałym, sprzedaj wszystko, co posiadasz i rozdaj ubogim, a będziesz miał skarb w niebie" (Mt 19, 21) ${ }^{24}$. Tę trudną drogę do zbawienia ubogi może jednak ułatwić sobie przez świadczenie dzieł miłosierdzia. Ambroży sprawę tę przedstawia w sposób następujący:

\footnotetext{
${ }^{20}$ Tamże 40, CSEL 32/2, 490, Kozera s. 49.

${ }^{21}$ De officiis ministrorum I 30, 149, PL 16, 72A, Abgarowicz s. 72.

${ }^{22}$ Por. tamze I 30, 144, Abgarowicz s. 70.

23 Por. tamże I 30, 148, Abgarowicz s. 71-72.

${ }^{24}$ Por. De Nabuthae 58, CSEL 32/2, 503, Kozera s. 63.
} 
„Wszystko, co przekazałeś biedakowi, obraca się na twoją korzyść. Staje się twoim zyskiem to wszystko, czego się pozbawiasz. Żywisz się tym pokarmem, który dałeś biedakowi, gdyż na tym właśnie polega zysk, że kto jest miłosierny dla biedaka, sam żywi się. Miłosierdzie sieje się bowiem na ziemi, a wyrasta ono w niebie. Zasadza się go w biedaku, a pędy puszcza u Boga"25.

W ten sposób święty Ambroży z Mediolanu, jak to już wcześniej w literaturze patrystycznej uczynił choćby Klemens Aleksandryjski, uznaje, że człowiek bogaty może być zbawiony, jeśli nawet posiada prywatną własność ziemską, która przynosi mu wielkie dobra, o ile z tej własności, do której prawa Ambroży ludziom bogatym nigdy wprost nie odmawia, umie we właściwy sposób korzystać, czyli dzielić się wynikającymi z niej dobrami, z ludźmi, którzy potrzebują pomocy materialnej.

\section{RIGHT TO PROPERTY AND MANNER HER USE \\ IN THE LIGHT „DE NABUTHAE HISTORIA” OF ST. AMBROSIUS}

(Summary)

Saint Ambrosius from Milan, as already earlier in patristic literature made even if Clemens from Alexandria, acknowledges, that rich man can be saved, if even he possesses private property, which brings him great goods, if from this property, to of which right Ambrosius to rich people never directly does not refuse, knows in proper manner to profit, this means to split with goods, which one possesses with men, whiches need of material help.

${ }^{25}$ Tamże 53, CSEL 32/2, 498, Kozera s. 58. 